RESUMO: Neste trabalho temos o objetivo de analisar as cartas de liberdade registradas nos livros de notas do Cartório de Notas $1^{\circ}$ Ofício de Jataí, no período de 1872 - ano de abertura do Cartório a 1888 - ano da abolição da escravidão no Brasil. Intentamos traçar o perfil dos/as libertos/as, destacando sexo, idade, cor e procedência, elucidando ainda, as questões concernentes à relação entre senhores e escravizados, percebendo estratégias políticas de ambos na negociação da liberdade e as formas de alforria registradas: condicional, sem ônus ou comprada pelo escravizado. Intenta-se com isso, perceber a dinâmica da escravidão em Jataí, dialogando com a historiografia produzida sobre o tema em Goiás e em outras regiões do país.

Palavras-chave: diplomacia; Governo Stroessner; aproveitamento hídrico.
ABSTRACT: This paper aims to analyze letters of freedom registered in the notary journals of the First Notary's Office of Jataí between 1872 - opening year of the Notary's Office - and 1888 - year of slavery abolition in Brazil. We intend to outline manumitted people profile, highlighting sex, age and color, as well as to elucidate the relationship between masters and enslaved people, noticing political strategies regarding freedom negotiation and registered manumissions forms: conditional, free or bought. Therefore, we aim to understand slavery dynamics in Jataí, in dialogue with the historiography produced on the topic in Goiás and other regions of Brazil.

Keywords: freedom; manumission; Jataí.

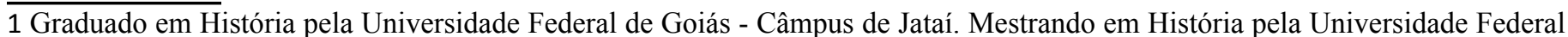
de Goiás - Câmpus Goiânia. Integrante do projeto de pesquisa Escravidão e Emancipação no Sudoeste de Goiás: conflitos, acordos e expectativas - da Universidade Federal de Jataí. E-mail: lucasrodrigues211@hotmail.com.

2 Doutor em História pela Universidade Federal de Uberlândia (2019). Mestre em História pela Pontifícia Universidade Católica de Goiás (2011). Licenciado em História pela Universidade Estadual de Goiás (2007). É professor no Curso de licenciatura em História da Universidade Federal de Jataí. E-mail: murilo_borges_silva@ufg.br. 
Escravidão e liberdade: abordagens historiográficas

A historiografia sobre escravidão negra no Brasil é considerada uma área consolidada, tendo ao longo do tempo passado por viradas interpretativas e epistemológicas, seguindo as variantes da escrita da história, a utilização de novas fontes e o entrecruzamento delas. A obra Casa Grande e Senzala (1933) de Gilberto Freyre desponta como uma das primeiras a se debruçar sobre aspectos culturais da presença/contribuição dos negros escravizados no Brasil, porém sua interpretação a respeito das relações entre senhores e escravizados é construída de forma paternalista, que de certo modo suaviza as mazelas do cativeiro, as violações da dignidade humana dos africanos e afro-brasileiros.

Por volta da década de 1950 a chamada Escola Paulista de Sociologia, protagonizou as pesquisas sobre as relações raciais no Brasil patrocinadas pela Organização das Nações Unidas para a Educação, a Ciência e a Cultura (UNESCO). As pesquisas buscavam identificar como a sociedade brasileira lidava com o passado escravista, as correlações entre raça e as hierarquizações sociais, ou seja, as possíveis (des)continuidades na trajetória dos negros no Brasil, em estudo comparado com outros países que sofreram o impacto do escravismo/racismo estrutural. Neste período, o materialismo histórico estava altamente em voga no cenário acadêmico brasileiro, e desta feita, as pesquisas realizadas pelo grupo foram produzidas a partir dessa perspectiva interpretativa.

Nessas produções a relação senhor e escravizado foi analisada tendo como pressupostos o econômico e a relação base/superestrutura. O negro escravizado foi visto como um ser destituído de autonomia, de capacidade de forjar redes de sociabilidade - como por exemplo relações familiares. Constituía-se, nesta perspectiva, como peça na engrenagem do sistema escravista brasileiro, devido a violência e extrema exploração do cativeiro (QUEIRÓZ, 2007; SCHWARTZ, 2001).

As interpretações até então (década de 1960/1970) ou reconheciam as hierarquizações, o racismo e as mazelas da escravização de forma suavizada e paternalista - como feito por Freyre na década de 1930 - ou destituíam agências e possibilidades de autonomia de negros e negras que tinham sua vida marcada pela condição de cativos. Desse modo, as experiências dos/as escravizados não figuravam nas páginas da história. A atuação desses sujeitos estava limitada a submissão, passividade, animalização, ou revoltas contra feitores, capitães do mato e senhores. A desumanização do corpo negro, bem como do indígena, e a sua constituição enquanto não-ser estava chancelada pela academia, ao considera-los selvagens, destituídos de cultura e sem agenciamento político, representando um atraso para a nação.

Por volta da década de 1980, a historiografia brasileira sobre a escravidão começa a ser reinterpretada, sendo fortemente influenciada pela aproximação teórica e política com as produções de Thompson. A "história vista de baixo", ou "história dos de baixo", começa a ganhar ressonâncias no Brasil pelo fato de que até então a experiência negra não havia sido trabalhada pela historiografia, culminando na falta de reconhecimento e historicização da atuação política dos escravizados.

Os conceitos de modo de produção, exploração e determinação, um tanto quanto abstratos e generalizantes, ajudaram a construir as concepções subjugação e passividade do escravizado brasileiro frente ao sistema escravista, dificultando a análise das especificidades das relações entre 
senhores e escravizados.

As obras produzidas no Brasil a partir de inspirações teóricas e políticas thompsonianas, como bem destacado por Silvia Hunold Lara, buscaram perceber a atuação dos escravizados enquanto agentes da transformação histórica, não se tratando

\begin{abstract}
Apenas e simplesmente de passar a estudar o modo de vida dos escravos ou a visão escrava da escravidão. A "inclusão dos excluídos" vem acompanhada, necessariamente, de uma nova abordagem na análise da relação senhor-escravo. Ao tratarmos de escravidão, ou de qualquer outro tema histórico, lembramos, com Thompson, que as relações históricas são construídas por homens e mulheres num movimento constante, tecidas através de lutas, conflitos, resistências e acomodações, cheias de ambiguidades. Assim, as relações entre senhores e escravos são frutos das ações de senhores e escravos, enquanto sujeitos históricos, tecidas nas experiências destes homens e mulheres diversos, imersos em uma vasta rede de relações pessoais de dominação e exploração. (LARA, 1995, p. 46)
\end{abstract}

A historiografia desde então tem produzido novas perspectivas e abordagens para os estudos da escravidão negra no Brasil, percebendo os conflitos, os acordos e as negociações entre senhores e escravizados, bem como possibilitando a leitura da família escrava como forma de resistência a dominação do/no cativeiro. Essas novas perspectivas estão filiadas ao desvelar da experiência escrava, buscando trazer ao palco o escravizado como sujeito histórico que "através de suas práticas cotidianas, costumes, lutas, resistências, acomodações e solidariedades, de seus modos de ver, viver, pensar e agir construiu, junto com os senhores, isso que no final das contas, chamamos de 'escravidão', de 'escravismo'"' (CASTRO, 1997, p. 58; LARA, 1995, p. 47).

Esse novo modo de fazer história, que lança mão de uma gama de fontes e entrecruzamento entre elas, como periódicos, cartas de liberdade, inventários, processos crimes, ações de liberdade, censos demográficos etc., deu novos contornos para a trajetória do escravizado no Brasil. Pretendeu-se, ainda, questionar/reinterpretar as análises feitas tanto por Freyre quanto pela "Escola Paulista de Sociologia". Neste sentido, a historiografia, a partir dos anos de 1980, começa a perceber novos contornos na história da escravidão negra no Brasil, principalmente em relação à atuação política e estratégica do escravizado.

O escravo coagido pelo sistema, o escravo sem espaços de autonomia, o escravo que sofre uma imposição inquestionável de dominação, cede lugar ao escravo que faz uma leitura das relações que o permeiam, ao escravo que costura espaços onde possa se mover, ao escravo que se constitui culturalmente, que tem consciência política, ao escravo que faz uma leitura das relações de dominação e que sabe jogar com ela, tirar proveito, por fim, ao escravo que exerce poder na constituição do próprio exercício de dominação. (ADOLFO, 2014, p. 106)

Na medida em que os escravizados fazem uso de sua consciência política para tecerem suas relações com sujeitos livres e libertos, construindo, dessa maneira, redes de sociabilidade e solidariedade capazes de auxiliá-los na negociação da liberdade, ou quando usam dessa consciência, do aprendizado no cativeiro, para forjar uma boa relação com os senhores, passam a se constituírem como agentes sociais, que buscam uma maior autonomia sobre suas próprias vidas, que questionam, de forma estratégica, o poder moral dos senhores (MACHADO, 2014, p. 29).

Um importante acontecimento que vai legitimar juridicamente o posicionamento desse escra- 
vizado sujeito de sua própria história é a promulgação da Lei do Ventre Livre em 1871. A partir de então, o escravizado poderia ter acesso aos mecanismos jurídicos a fim de assegurar a liberdade, apesar da prerrogativa de ser representado juridicamente por um sujeito livre. A referida Lei também pode ser interpretada como um questionamento do poder senhorial, pois a partir de então, o Estado passava a intervir nas relações particulares de senhores e escravizados, e, por mais que a postura não fosse abertamente favorável à libertação, brechas jurídicas foram criadas, abrindo novos caminhos para a liberdade.

A partir da promulgação da lei, novas formas de perceber e conceber a liberdade foram estabelecidas, sendo elas a prerrogativa do ventre livre, o reconhecimento do pecúlio e a exigência da matrícula do escravizado.

A lei de 1871 transformou esse cenário, ao garantir alguns direitos de fato aos cativos e colocar em xeque políticas de domínio senhorial até então cruciais na manutenção da disciplina da escravaria, principalmente no que se referia à prerrogativa senhorial de libertar seus cativos. (GOMES; MACHADO, 2015, p. 46)

Por fim, podemos analisar as brechas e encaminhamentos criados a partir desta promulgação como facetas que corroboram com a perspectiva de construção de uma abolição da escravidão negra no Brasil de forma lenta e gradual, posicionamento defendido por boa parte dos políticos e pela sociedade brasileira da época, que intentavam conceder a liberdade aos escravizados, desde que esse processo fosse realizado sem abalar as esferas políticas, econômicas e sociais de um Estado em construção, que pretendia ser liberal (CHALHOUB, 1990, p. 158; GRINBERG, 2008, p. 58; MATTOSO, 2003, p. 177-178). De acordo com Grinberg,

É impossível desvincular a lei de 1871 do projeto de emancipação gradual levado à frente pelo governo. Se, por um lado, ela golpeou "a ascendência moral dos senhores sobre seus cativos", por outro marcou o posicionamento do governo sobre a forma como deveria ser encaminhada a questão da liberdade dos escravos, já, àquela altura, irreversível. (GRINBERG, 2008, p. 57)

Segundo Mattoso (2003) os caminhos que levaram os escravizados do Brasil à liberdade foram vários: fugas, ameaças de crimes, levantes, as brechas criadas a partir da própria legislação do século XIX e a liberdade por meio de carta de alforria. Durante os anos de trabalho e convivência, o cativo poderia forjar comportamentos com a intenção de despertar no senhor algum apreço. Não foram incomuns registros de liberdade que mencionavam o bom comportamento do escravizado, os bons serviços prestados, a dedicação e amor a que serviu ao senhor e sua família, dentre outras descrições que qualificavam positivamente o escravizado e indicavam a construção de alguma afetividade ou reconhecimento dos serviços prestados. Esse tipo de ação por parte do cativo é concebida por nós como estratégias que poderiam influenciar o senhor na decisão de alforriá-lo ou não. 
Nelas, o escravo não parece com papel de vítima passiva, sem qualquer autonomia para viver sua vida, ou como alguém cuja obediência é mantida exclusiva ou principalmente pelo chicote. Se ele soube criar, mesmo nos estreitos limites de sua condição, espaços de invenção linguística, religiosa, musical, culinária, enganar o senhor, defender, sua família, sabotar, fugir e rebelar-se, o vemos aqui sabendo também seduzir, tornar-se cúmplice dos senhores, aproveitando oportunidades e locomovendo-se taticamente no sentido de tornar sua vida a melhor possível. (BELLINI, 1988, p. 73)

Percebendo as mudanças na dinâmica da escravidão, os senhores também fizeram uso político das alforrias, condicionando-as, na maioria das vezes, à sua vontade. Esse uso político das alforrias, de certo modo, servia como mecanismo de manutenção de controle dos senhores, ao exigirem dos escravizados comportamentos de obediência e fidelidade, servindo assim como ampla estratégia de produção de dependentes, de criação de uma dívida de gratidão para com o senhor, transformando os ex-escravizados em negros fiéis e submissos que se manteriam sempre ligados aos seus antigos proprietários (CHALHOUB, 1990; MATTOS, 1998).

Embora a historiografia reconheça, atualmente, a ação dos escravizados na luta pela alforria, no contexto da escravidão, ela deveria ser compreendida como uma expressão da vontade senhorial. Por outro lado, os escravizados também compreendiam essa estratégia política de seus senhores, e, durante o cativeiro, construíram um largo aprendizado no que concerne às possibilidades de obtenção da liberdade, forjando, assim, comportamentos que pudessem beneficiá-los.

A alforria não foi possível à maioria dos escravizados no Brasil, mas para os que conseguiram tal feito, ela apresentou múltiplos significados: liberdade de construir novos laços de amizade, família, relações de trabalho, modos e lugares de viver.

Apesar das dificuldades que a maioria encontrava para libertar-se do estigma de ter sido escravo, chegar à condição de liberto parecia estar simbolicamente associado a um renascimento [...] Em regra geral, o único bem do escravo era o seu próprio corpo, bem de que ele, com escravo, era apenas o portador, não o proprietário. A libertação, assim, devia significar como que a aquisição de um novo corpo, autônomo, diferente daquele que era propriedade do senhor. (BELLINI, 1988, p. 84)

Faz-se necessário explicitar que neste trabalho estamos compreendendo como estratégias dos escravizados a capacidade de leitura política do cativeiro, de construção de sentimentos, forjando relações com os senhores e com pessoas livres diversas, com vistas para a obtenção da liberdade. Esta interpretação está de acordo com o campo da história social da escravidão negra do Brasil construída a partir dos anos 1980, que considera o escravizado como sujeito histórico que soube lutar pela liberdade no sistema escravista.

Optamos pela grafia do termo escravizado ao invés de escravo que geralmente é o mais utilizado pela historiografia, por compreender que

Enquanto o termo escravo reduz o ser humano à mera condição de mercadoria, como um ser que não decide e não tem consciência sobre os rumos de sua própria vida, ou seja, age passivamente e em estado de submissão, o vocábulo escravizado modifica a carga semântica e denuncia o processo de violência subjacente à perda da identidade, trazendo à tona um conteúdo de caráter histórico e social atinente à luta pelo poder de pessoas sobre pessoas, além de marcar a arbitrariedade e o abuso da força dos opressores. (HARKOT-DE-LA-TAILLE; SANTOS, 2012, p. 8-9) 
Cabe destacar que Jatahy, embora distante dos centros de poder político, não esteve ausente dessas discussões. A dinâmica da escravidão e luta 'por liberdade na região, aproximou-se de outras localidades nacionais, guardadas suas particularidades. Daí a importância de um olhar cuidadoso para a história regional, de modo a articular e discutir as imbricações e distanciamentos entre local, regional e nacional.

\section{Alforrias nos livros de notas de Jatahy}

De acordo com a literatura memorialista, a região de Jatahy, localizada no sudoeste da Província de Goyaz, teve o seu processo de ocupação por não-indígenas iniciado por volta de $1836^{3}$. Uma primeira forma de comprovação em relação à presença de escravizados na Parochia do Divino Espirito Santo do Jatahy foi por meio da análise do primeiro censo demográfico brasileiro. O Recenseamento do Brazil foi realizado no ano de 1872, e aponta dados referentes a "raças", sexo, estado civil, religião, nacionalidade, instrução, idade e profissões dos habitantes de diversas regiões do país.

A referida Parochia possuía o total de um mil e oitocentos e quinze (1815) habitantes. Deste número, um mil e quinhentos (1500), ou 82,6\%, eram homens (820) e mulheres (680) que compunham a população livre, ao passo que trezentos e quinze (315) compunham a parcela de homens (168) e mulheres (147) escravizadas, o que representa um percentual de $17,4 \%$ da população do Distrito do Divino Espírito Santo do Jatahy, uma região predominantemente agropastoril e com um mercado de subsistência.

A documentação analisada durante a pesquisa foram seis livros de notas do Cartório de Notas $1^{0}$ Ofício de Jatahy. Tais registros nos permite averiguar a presença de escravizados na região desde o início das atividades, no ano de 1872. A documentação que nos possibilita analisar a presença dos escravizados antes de 1872 era, provavelmente, registrada nos cartórios da comarca de Rio Verde, e a estes registros ainda não foi possível termos acesso.

Os estudos sobre escravidão em Jatahy contam, basicamente, com as contribuições de Silva $(2011)^{4}$, que analisa principalmente os anos finais da escravidão e os primeiros anos do pós-abolição em Jatahy, com o intuito de perceber as diferentes perspectivas, negociações, conflitos e acordos de senhores e escravizados nos caminhos da abolição. A ausência de outros estudos, assim como as diferentes possibilidades de abordagens das fontes, sejam elas cartoriais ou paroquiais, denotam a necessidade de outras pesquisas sobre o tema, buscando descortinar a atuação dos diferentes grupos e sujeitos no processo de abolição da escravidão em Jatahy e demais localidades do sudoeste goiano.

A partir da análise dos livros de notas, conseguimos identificar o registro de dezoito cartas de alforria, que concedem a liberdade a vinte e dois cativos. Atento-me aos registros das cartas de alforria dos escravizados entre os anos de 1872 e 1888. A tabela a seguir nos mostra os registros

\footnotetext{
3 Embora, tradicionalmente, se afirme que o processo de ocupação de Jataí se deu com a chegada dos pioneiros a região, é preciso lembrar que populações indígenas já se encontravam ocupando essas terras.

4 SILVA, Murilo Borges. Pelos Caminhos da Abolição: Os últimos anos da escravidão e as experiências de liberdade em Jataí. Dissertação de Mestrado apresentada ao Programa de Pós-Graduação em História da Pontifícia Universidade Católica de Goiás. Goiânia, 2011.
} 
das alforrias por triênio.

TABELA 01 - Registro dos tipos de alforria por triênio

TRÊNIO CONDICIONAIS GRATUITA ONEROSAS

$\begin{array}{llll}1871 / 1873 & 1 & 1 & - \\ 1874 / 1876 & 1 & 1 & - \\ 1877 / 1879 & 1 & 1 & - \\ 1880 / 1882 & 1 & 1 & - \\ 1883 / 1885 & 1 & 1 & - \\ 1886 / 1888 & 1 & 1 & -\end{array}$

Fonte: Livros de Notas de 01 ao 06 do Cartório de Notas $1^{\circ}$ Ofício de Jatahy.

Verifica-se em Jatahy, e em consonância com a historiografia, a predominância de três formas de registros das alforrias: condicional (nessa modalidade há imposições que devem ser cumpridas pelo escravizado para que a liberdade seja efetivada), onerosa (quando o escravizado por meio do acúmulo de pecúlio obtém a alforria) e gratuita (liberdade concedida pelos senhores sem nenhuma exigência ou cobrança de pagamento). Desta forma, encontramos 7 alforrias condicionais, 7 alforrias onerosas e 4 gratuitas.

A alforria condicional se caracteriza como a promessa da liberdade feita pelo senhor, que seria efetivada após o cumprimento de algumas condições. O escravizado ficaria encarregado de cumprir cláusulas, como: mais alguns anos de prestação de serviços, a morte do senhor ou senhora, o casamento de filhos/as, dentre outras imposições que alongavam ainda mais o período de vivência no cativeiro.

Em Jatahy, podemos observar alguns casos, como o da escravizada Clemência, de mais ou menos 21 anos, que tem a liberdade "concedida" por Felippe Dias Vieyra e sua mulher Dimetildes Josefa Cansada, em 10 de janeiro de 1876. Os senhores justificam a concessão como uma forma de recompensa pelos bons serviços prestados, fidelidade, paciência e amor. Porém, a liberdade de Clemência está subordinada ao cumprimento de mais treze anos de trabalho. As alforrias condicionais, em sua maioria, apresentam como requisito de efetivação da liberdade o cumprimento de um prazo determinado de trabalho e representa, de modo geral, uma forma de estratégia de domínio dos senhores.

Para estes, além da garantia da prestação de serviços, a promessa da liberdade intentava despertar no escravizado o sentimento de gratidão e fidelidade, acalmando as possíveis revoltas e rebeldias dos escravizados, tendo em vista a aproximação da abolição. Os senhores estariam reafirmando seu poder moral sobre os escravizados e mantendo sob seu controle o encaminhamento 
da abolição.

Entretanto, os bons serviços prestados, os sentimentos de paciência e amor, descritos na alforria de Clemência, foram construídos no cotidiano, forjados ao longo de uma vida, constituindo-se como estratégias de resistência da escravizada que, certamente intentava a liberdade ou um "bom cativeiro". Portanto, os predicados de Clemência também devem "ser lidos sob a perspectiva de sua atuação por meio de táticas de convencimento e de lutas, de investimento para conseguir sua liberdade, ainda que condicional" (SANT'ANNA, 2005, p. 150).

Podemos analisar ainda o desenrolar da liberdade de Pedro, cativo que em 21 de setembro de 1874 tem sua carta de liberdade condicional registrada pelos seus senhores, José de Carvalho Bastos e sua mulher Ana Cândida de Gouveia. Como condição para gozar da liberdade, o cativo deveria prestar serviços à família do seu senhor por mais seis anos. Se compararmos com as condições impostas em outras cartas de alforria, o prazo estipulado para Pedro tornar-se livre era, razoavelmente, pequeno. Porém, em 8 de setembro de 1877, cerca de três anos após o registro da liberdade condicional, seus senhores resolvem alforriá-lo definitivamente, conforme consta em registro encontrado no Livro de notas:

\begin{abstract}
Dizemos nós Jose de Carvalho Bastos e Ana Cândida de Gouveia, abaixo assinados, que entre os bens que possuímos livres e dezembarassados, he bem assim hum escravo de nome Pedro, crioulo, a quem por amor que temos, e em recompensa dos bons servissos que nos tem prestado e rigorosa obediencia que nos tem apprezentado a tempos lhes passamos escriptura de liberdade sugeito a comprimento de alguns annos; agora porem rezolvemos a dar por concluido o dever a que o mesmo era obrigado e dar-lhe desta dacta em diante plena liberdade como se nascesse de ventre livre. E por ser essa a nossa vontade sem constrangimento de parte alguma, mandamos passar a presente que assignamos. Freguesia do Jatahy oito de setembro de mil oito centos e settenta sette. (CARTA DE LIBERDADE, 1887).
\end{abstract}

Podemos observar que os senhores Jose de Carvalho Bastos e Ana Cândida de Gouveia destacam que a concessão da liberdade definitiva se dá por ser essa a sua vontade, reafirmando a ideia de que a alforria era uma prerrogativa senhorial. Além disso, na perspectiva senhorial, a descrição das motivações e dos sentimentos: o amor que sentiam pelo escravizado, a recompensa pelos bons serviços prestados e rigorosa obediência, servem para reafirmar seu caráter paternalista e benevolente. Além disso, incute no imaginário do período as prerrogativas de qual deve ser o comportamento de um bom escravo. O discurso dos senhores pode ser na verdade uma estratégia de domínio, que busca despertar no liberto sentimento de gratidão e lealdade, fazendo com que Pedro, apesar do gozo da liberdade, se mantivesse por perto, tornando-se grato e obediente aos seus antigos senhores.

No entanto, faz-se necessário interpretarmos as escolhas de Pedro. Devido a sua idade - mais ou menos quarenta e oito anos -, o mesmo já havia aprendido a negociar, forjar sentimentos, oportunidades e relações com os senhores com vistas na liberdade. Portanto, devemos perceber que os sentimentos descritos na alforria se constituem como táticas de convencimento, construídas nas relações cotidianas de Pedro com seus senhores, buscando convencê-los pela decisão da liberdade.

Por outro lado, precisamos nos advertir sobre esse olhar dicotômico que muitas vezes lançamos a fonte, pois, conforme nos alerta Chalhoub (1990), a relação entre senhor e escravizado nem 
sempre se dá de forma plástica ou encenada. Não é impossível supor uma relação de afetividade entre eles, que poderia nascer no decorrer do tempo. Nem sempre escravo e senhor estavam tramando estratégias para chegar a um determinado objetivo (CHALHOUB, 1990, p. 150).

Ainda em relação às alforrias condicionais, verificamos que em 12 de janeiro de 1876, consta no livro número 01 do Cartório de Notas, o registro da carta de alforria de Sebastião, que possuía sete anos mais ou menos. Para gozar de plena liberdade, o pequeno escravizado teria que esperar pelo falecimento de seus senhores. Ou seja, sua alforria era condicional, e mesmo estando registrada em cartório, não tornava o cativo livre, pois Sebastião continuava servindo aos senhores, estava sujeito a receber castigos, e devia cumprir todas as ordens que lhe fossem destinadas. O que restava para o escravizado nessa situação era apenas esperar a morte dos seus senhores, o que poderia levar dias, meses ou anos. Até que acontecesse a morte dos seus senhores, "o outro dia seria o mesmo dia. O novo seria apenas uma promessa, uma possibilidade de, no futuro, romper com o velho" (SANT'ANNA, 2005, p. 150).

Nos casos em que o pleno gozo da liberdade estava relacionado ao falecimento dos senhores, além da incerteza acerca do tempo de serviços no cativeiro, outras dúvidas rondavam a trajetória para a liberdade. O não cumprimento da promessa de alforria por parte dos herdeiros, era uma delas. Tendo em vista que o acordo firmado entre o antigo senhor e o escravizado poderia não ser lucrativo para o novo dono, este tinha possibilidade de agir no intuito de revogar ou simplesmente ignorar a carta de alforria. Casos como estes não foram incomuns e renderam longos e calorosos processos, chamados de ações de liberdade, sobretudo no Rio de Janeiro e São Paulo, movidos por escravizados que requeriam, por intermédio de um representante livre, o direito de liberdade. Segundo Chalhoub:

[...] o falecimento do senhor era para os escravos o início de um período de incerteza, talvez semelhante em alguns aspectos à experiência de ser comprado ou vendido. Eles percebiam a ameaça de se verem separados de familiares e de companheiros de cativeiro, havendo ainda a ansiedade da adaptação ao julgo de um novo senhor, com todo um cortejo desconhecido de caprichos e vontades. Era problemático também fazer valer os direitos conquistados ao antigo senhor [...] Os escravos ficavam preocupados em garantir os direitos supostamente adquiridos através da doação do senhor, mas frequentemente encontravam a oposição de herdeiros decididos a impedir qualquer subtração ao seu legado - mesmo que para isso tivessem de dar sumiço em testamentos e cartas de alforria. (CHALHOUB, 2009, p. 111-112).

A segunda forma de alforria encontrada foi aquela que era comprada pelo cativo, por meio do acúmulo do pecúlio. A compra de alforrias pelos escravizados é reconhecida na historiografia desde o período colonial, estando vinculadas às práticas costumeiras, que necessariamente perpassavam pela vontade do senhor em negociar o preço e as condições da liberdade dos cativos. A promulgação da Lei do Ventre Livre representa o reconhecimento legal do acumulo de pecúlio, que passa a ser assegurado pela legislação, desde que as atividades econômicas fossem realizadas em horário livre. A Lei 2040, de 28 de setembro de 1871, reza em seu artigo 40 ser "permittido ao escravo a formação de um pecúlio com o que the provier de doações, legados e heranças, e com o que, por consentimento do senhor, obtiver do seu trabalho e economias" ${ }^{\prime 5}$.

5 DISTRITO FEDERAL. CASA CÍVIL. LEI 2040, de 28 de setembro de 1871. Disponível em: http://www.planalto.gov.br/ccivil_03/leis/lim/LIM2040.htm. Acesso em: 20 dez. 2019. 
O reconhecimento legal do pecúlio representa a interferência do Estado na relação entre senhores e escravizados, pois tendo o escravizado a quantia suficiente para comprar a sua liberdade, estaria respaldado pelo direito de acumular economias e negociar a alforria. A prerrogativa senhorial de condicionar a negociação da liberdade a sua vontade deixaria de existir embora ainda exercesse poder sobre essa decisão, pois, poderiam dificultar o processo de concessão da alforria.

Os senhores não poderiam impedir no cotidiano que os escravos fizessem suas economias, e depois não poderiam se negar a conceder-lhes a alforria por indenização de preço porque tal direito dos negros ficava estabelecido no artigo quarto, parágrafo segundo, da lei de 28 de setembro. Apesar das ambiguidades e vacilações do texto - imposições da composição política necessária à aprovação do texto -, havia agora chances mais reais de os escravos atingirem a alforria mesmo contra a vontade dos senhores. (CHALHOUB, 1990, p. 158)

Sobre a compra de alforria, podemos observar o registro em 12 de maio de 1879, em que o escravizado Bernardo Africano, de cinquenta e dois anos de idade mais ou menos, paga aos seus senhores Joaquim Fabiano Vilela e sua mulher Graciana Antonia da Silveira, a quantia de duzentos e sete mil reis, se comprometendo ainda a pagar em liberdade a quantia de quinhentos e noventa mil reis, completando o pagamento de sua alforria. As alforrias compradas pelos escravizados de forma "parcelada" configuram a coartação, onde o cativo, dependendo das condições do senhor, poderia receber sua liberdade e pagá-la por meio do trabalho livre - forma possivelmente adotado pelo escravo Bernardo - ou, com o pecúlio acumulado em seus dias livres, ir pagando aos poucos seu senhor para completar o valor correspondente a sua alforria (FERREIRA, 2007, p 116-120).

Com a morte do/s senhor/es, o valor do escravizado poderia ser "dividido" em partes, tendo cada herdeiro o direito sobre uma parte do cativo. Nestes casos, o escravizado poderia ter complicações na luta pela liberdade, devido ao fato de nem todos os herdeiros entrarem em consenso sobre a sua liberdade. Possivelmente foi o que aconteceu com Francisco, de vinte anos, que em 28 de dezembro de 1876 pagou por sua liberdade a João Joaquim Furtado à parte que Ihe cabia, no valor de cento e quarenta mil reis.

Por fim, a última forma de alforria identificada na documentação, foi a liberdade sem ônus, normalmente justificada pelos bons serviços prestados, pela dedicação ou mesmo pelo amor que os senhores tinham pelo escravizado. Maria Africana, em fevereiro e março de 1878, conseguiu obter sem ônus a liberdade de dois senhores, Antonio Crysostomo de Castro e Antonio Crysostomo de Castro Junior, passando, possivelmente, a gozar da liberdade. As alforrias "gratuitas" também fazem parte da política de domínio senhorial, e sobre as expectativas do senhor em relação a essa "concessão", Silva afirma que:

Nesse caso, normalmente, o proprietário libertava o escravo pelo reconhecimento dos bons serviços prestados e pela fidelidade do escravo, dispensando o alforriado de qualquer obrigação com o senhor, embora fosse evidente que o senhor esperasse do escravo que recebia a liberdade o reconhecimento de sua benevolência. (SILVA, 2011, p. 96)

Mesmo sabendo que o número de cartas de liberdade registradas nos livros de notas podem não corresponder ao total de alforrias no período, podemos traçar um perfil dos libertos em Jatahy. 
Dos vinte e dois libertos, conseguimos presumir a idade de onze deles, estando em sua maioria na faixa etária de trabalho, ou seja, entre 14 a 35 anos $^{6}$. A partir da análise da faixa etária, percebemos a capacidade de articulação dos cativos na luta pela liberdade, pois, apesar da idade estar associada ao período de geração de lucros para os senhores a partir da exploração de sua mão-de-obra, eles souberam empreender estratégias de convencimento, forjar sentimentos nos senhores, construir caminhos nas brechas cotidianas visando a liberdade.

Alguns historiadores como Mattoso (2003) afirmam que a alforria era alcançada com mais facilidade pelas mulheres, por diversas razões, como: a proximidade com a casa-grande ou práticas para além dos afazeres domésticos com o senhor, tornando mais fácil o caminho para a liberdade. Como já mencionado anteriormente, os estudos sobre os anos finais da escravidão em Goiás são poucos, sendo um deles a dissertação de mestrado intitulada Tecendo a liberdade: alforrias em Goiás no século XIX, de Leite (2000). As análises da autora nas regiões de Santa Cruz e Meia Ponte, apontam um percentual maior de alforrias "concedidas" para escravizados do que escravizadas, destoando da historiografia "tradicional". Nos registros dos livros de notas de Jatahy, os dados nos mostram certo equilíbrio entre os forros: dos vinte e dois libertos, 12 deles eram mulheres e 10 homens. A seguir, apresentamos uma tabela que demostra a idade dos escravizados por década:

\begin{tabular}{lc}
\hline \multicolumn{2}{c}{ TABELA 01 - Registro dos tipos de alforria por triênio } \\
\hline IDADE & NÚMEROS DE ESCRAVOS \\
$1-10$ & 1 \\
$11-20$ & 3 \\
$21-30$ & 2 \\
$31-40$ & 1 \\
$41-51$ & 2 \\
52 ou mais & 2 \\
Não informado & 11
\end{tabular}

Fonte: Livros de Notas números 01 ao 06 do Cartório de $1^{\circ}$ Ofício de Jatahy

Apesar de localizar-se na região atualmente conhecida como centro-oeste brasileiro, sendo Goyaz uma província afastada dos portos de entrada do tráfico transatlântico - Salvador e Rio de Janeiro -, nota-se, desde o período colonial, a presença de escravizados africanos em Goiás, tendo como rotas de entradas os caminhos de São Paulo e Rio de Janeiro (LEMKE, 2013, p. 125). Apesar da ocupação de não-indígenas em Jatahy ter ocorrido apenas no século XIX, por volta de 1836, após a promulgação da Lei de 1831 que estabelece a proibição do tráfico de escravizados estrangeiros, constatamos ali a presença de africanos escravizados na região.

Bernardo africano, Maria africana e Mariana de nação, assim descritos em seus registros de

$\overline{6 \text { Mesmo com o }}$ alerta da autora em relação as possíveis variações nas regiões do país, utilizamos a tabela de Mattoso para considerarmos o escravo dentro da faixa etária de trabalho. MATTOSO, 2003. p. 86. 
liberdade, são provas da presença de escravizados estrangeiros em Jatahy. Cabe ainda ressaltar que, as dificuldades de 'adaptação' social, linguística e cultural, além da dificuldade de viver como cativos no Brasil, não os impediu de lutar e estabelecer estratégias de negociação com os senhores para alcançar a liberdade.

Entretanto, a maioria dos escravizados que conquistaram a alforria em Jatahy, segundo registros consultados, nasceram no Brasil, 16 no total. Fazemos esta afirmação levando em consideração a descrição de procedência e cor. Esses dados corroboram com a perspectiva de Mattos (1998), que atribui aos escravizados nascidos no Brasil um largo aprendizado de uma política de negociação desenvolvida no campo dos costumes, assim como do poder privado dos senhores, tendo como miragem a liberdade (MATTOS, 1998, p. 192). Em três casos, a alforria é silenciosa em relação a informação da procedência dos sujeitos.

\section{Considerações finais}

As análises acerca dos acordos, negociações e disputas no encaminhamento da emancipação da população negra escravizada no Brasil compõem uma historiografia consolidada no cenário nacional e internacional. Quando nos dedicamos a problematizar a historiografia regional sobre o tema, fica evidente que os estudos referentes aos anos finais da escravidão em Goiás precisam ser ampliados, para que os cenários da abolição em diferentes localidades da província sejam descortinados, trazendo à tona a atuação dos diferentes grupos sociais envolvidos neste processo, sobretudo a atuação de negros e negras.

Os registros de liberdade nos livros de notas, mesmo que não nos dê suporte para afirmações mais generalizantes acerca do encaminhamento da liberdade em Jatahy, por não corresponderem ao total de libertações no período analisado, tendo em vista as outras formas possíveis de obtenção da liberdade, além da carta de alforria registrada em cartório, aliado ainda a pouca produção da historiografia regional sobre os últimos anos da escravidão em Goiás, nos faz perceber algumas características da atuação de senhores e escravizados na negociação pela liberdade.

Podemos identificar nas alforrias concedidas de forma condicional a construção de estratégias por parte dos senhores da região, pois estes, ao conceder a liberdade condicionada a acontecimentos, como a sua morte ou o casamento de seus filhos e filhas, ou, ao cumprimento de algumas obrigações antes do pleno gozo da liberdade pelo escravizado, estava fazendo uso da política de domínio senhorial. A promessa de liberdade gerava expectativas nos escravizados, que por sua vez, mantinham o bom comportamento, assim como a boa prestação de serviços ao senhor. Provavelmente, esses futuros libertos se tonariam ex-escravizados que nutririam sentimentos de gratidão e lealdade pelo senhor.

Em contrapartida, compreendemos a atuação dos escravizados na luta pela liberdade, percebendo-os como sujeitos históricos que lutaram para se livrar do jugo do cativeiro. As diversas formas de registro das cartas de alforria demostram que durante o período do cativeiro, apesar da condição subalterna, os escravizados souberam tecer boas relações com os senhores, escolhendo o caminho do bom comportamento, prestando bons serviços, forjando sentimentos de lealdade e afeição para 
conseguir a liberdade.

Ao destacarmos as táticas e estratégias de resistência e negociação dos escravizados, estamos nos dedicando a historicizar o escravismo brasileiro, considerando a atuação dos múltiplos sujeitos envoltos neste processo histórico. De maneira alguma há a tentativa de negar ou suavizar todo o processo de violência e tentativa de destituição da humanidade dos/as escravizados, nossas intenções consistem em romper com as concepções de um escravizado passivo e submisso, sem consciência política, ou capacidade de luta pelo fim da escravidão.

\section{REFERÊNCIAS}

Fontes:

\section{Cartório de $1^{\circ}$ Ofício de Notas de Jataí-GO}

Livros de Notas no 01, 02, 03, 04, 05 e 06 (cartas de liberdade), 1872 - 1888.

Bibliografia:

ADOLFO, Roberto Manoel Andreoni. A emergência do escravo-agente na historiografia brasileira da escravidão entre os anos 1970 e 1980. Dissertação (Mestrado em História) - Faculdade de Ciências e Letras de Assis, Universidade Estadual Paulista, Assis, 2014.

BELLINI, Ligia. Por amor e por interesse: a relação senhor-escravo em cartas de alforria. In: REIS, João Jose. (org). Escravidão e Invenção da Liberdade: estudos sobre o negro no Brasil. Editora Brasiliense, 1988, p. 73-86.

CASTRO, Hebe. História Social. In: CARDOSO, Ciro Flamarion; VAINFAS, Ronaldo (org.). Domínios da História. Rio de Janeiro: Elsevier, 1997, p. 45-59.

CEVASCO, Maria Elisa. A formação dos Estudos Culturais. In: CEVASCO, Maria Elisa. Dez lições sobre Estudos Culturais. São Paulo: Boitempo, 2003. p. 60-79.

CHALHOUB, Sidney. Visões da liberdade: uma história das últimas décadas da escravidão na corte. São Paulo: Companhia das Letras, 1990.

FERREIRA, Roberto Guedes. A amizade e a alforria: um trânsito entre a escravidão e a liberdade (Porto Feliz, SP, Século XIX). Afro-Ásia, Salvador, v. 35, p. 83-141, 2007.

GOMES, Flávio; MACHADO, Maria Helena P. T. Da abolição ao pós-emancipação: ensaiando alguns caminhos para outros percursos. In: CASTILHO, Celso Thomas; MACHADO, Maria Helena P. T. (org.). Tornando-se Livre: Agentes Históricos e Lutas Sociais no Processo de Abolição. São Paulo: Editora da Universidade de São Paulo, 2015.

GRINBERG, Keila. Liberata: a lei da ambiguidade - ações de liberdade da Corte de Apelação do Rio de Janeiro no século XIX. Rio de Janeiro: Centro Edelstein de Pesquisas Sociais, 2008.

HARKOT-DE-LA-TAILLE, Elizabeth; SANTOS, Adriano Rodrigues. Sobre escravos e escravizados: percursos discursivos da conquista da liberdade. Simpósio Nacional Discurso, Identidade e Sociedade, 3., 2012, Campinas. Anais [...]. Campinas: Universidade Estadual de Campinas, 2012. 
LARA, Silvia Hunold. BLOWIN'IN THE WIND: E. P. Thompson e a experiência negra no Brasil. Projeto História, São Paulo, v. 12, p. 43-56, 1995.

LEITE, Clara Duran. Tecendo a liberdade: alforrias em Goiás no século XIX. Dissertação (Mestrado em História) - Universidade Federal de Goiás, Goiânia, 2000.

LEMKE, MARIA. O Caminho do Sertão: Notas Sobre a Proximidade Entre Goiás e África. Politeia, Vitória da Conquista, v. 13, p. 115-132, 2013.

MACHADO, Maria Helena Pereira Toledo. Crime e Escravidão: Trabalho, Luta e Resistência nas Lavouras Paulistas (1830-1888). 2. ed. São Paulo: Edusp, 2014.

MATTOS, Hebe Maria. Das cores do silêncio: os significados da liberdade no sudoeste escravista - Brasil século XIX. Rio de Janeiro: Nova Fronteira, 1998.

MATTOSO, Kátia M. de Queirós. Ser escravo no Brasil. São Paulo: Brasiliense, 2003.

QUEIROZ, Suely Robles. Escravidão Negra e Debate. In: FREITAS, Marcos Cezar. Historiografia brasileira em perspectiva. São Paulo: Contexto, 2007. p. 103-117.

SANT'ANNA, Thiago. Mulheres goianas em ação: práticas abolicionistas, práticas políticas. (18701888). Dissertação (Mestrado em História)- Universidade de Brasília, Brasília, 2005.

SCHWARTZ, Stuart B. Escravos, roceiros e rebeldes. Bauru: EDUSC, 2001.

SILVA, Murilo Borges. Pelos Caminhos da Abolição: Os últimos anos da escravidão e as experiências de liberdade em Jataí. Dissertação (Mestrado em História) - Pontifícia Universidade Católica de Goiás, Goiânia, 2011.

Recebido em: 21 de abril de 2020. Aprovado em: 31 de maio de 2020. 